\title{
液体クロマトグラフィーによるリン酸八カルシウムのタンパク質吸着特性
}

\author{
太田一史・門間英毅・高橋＼cjkstart聡・小林偉男 \\ 工学院大学工学部応用化学科, 192-0015 東京都八王子市中野町 2665-1
}

\section{Adsorption Characteristics of Proteins on Octacalcium Phosphate by Liquid Chromatography}

\author{
Kazushi OHTA, Hideki MONMA, Satoshi TAKAHASHI and Hideo KOBAYASHI \\ Department of Applied Chemistry, Faculty of Engineering, Kogakuin University, 2665-1, Nakano-cho, Hachioji-shi, Tokyo $192-0015$
}

\begin{abstract}
Adsorption characteristics of proteins on $\mathrm{Ca}_{8} \mathrm{H}_{2}\left(\mathrm{PO}_{4}\right)_{6} \cdot 5 \mathrm{H}_{2} \mathrm{O}$ (OCP) were investigated by liquid chromatography using a potassium phosphate buffer (KP) as an eluant. Proteins as sample molecules with different isoelectric point (pI) values were adsorbed on the OCP surface equilibrated with $0.01 \mathrm{~mol} \cdot \mathrm{dm}^{-3}$ $\mathrm{KP}$, and were desorbed with increasing $\mathrm{KP}$ molarity. Basic proteins with $\mathrm{pI}>6.8$ were eluted by a using $\mathrm{KCl}$ or $\mathrm{MgCl}_{2}$ linear molarity gradient, whereas acidic proteins with $\mathrm{pI}<6.8$ were not eluted even at 0.3 mol . $\mathrm{dm}^{-3} \mathrm{KCl}$ or $\mathrm{MgCl}_{2}$. Such a chromatographic behavior was similar to that of $\mathrm{Ca}_{10}\left(\mathrm{PO}_{4}\right)_{6}(\mathrm{OH})_{2}(\mathrm{HAp})$. It is presumed that acidic and basic proteins were adsorbed on the $\mathrm{Ca}^{2+}$ ions ( $\mathrm{Ca}$ site) with positive charge and the $\mathrm{PO}_{4}{ }^{3-}$ ions ( $\mathrm{P}$ site) with negative charge on the surface of $\mathrm{OCP}$, respectively. The amount of $\mathrm{Ca}$ site on the OCP surface were considered to be more than that on the HAp surface from average elution molarities for acidic and basic proteins. As the crystal surface structure of OCP (h00) was similar to that of HAp $(h 00)$, acidic proteins were preferentially adsorbed on the $(h 00)$ of $\mathrm{OCP}$ crystal with a blade-shaped form.

[Received January 19, 1999; Accepted March 26, 1999]
\end{abstract}

Key-words : Octacalcium phosphate, Hydroxyapatite, Liquid chromatography, Adsorption, Protein

\section{1. 緒 言}

リン酸カルシウムを充填剂とする液体クロマトグラフィー は，その歴史が古く，各種生体高分子の精製や分離に利用され てきた1) 3). しかし，当時使用された充填剂には物質名や性 状の不明なものが多い. Tiselius らは結晶性の $\mathrm{Ca}_{10}\left(\mathrm{PO}_{4}\right)_{6}$ $(\mathrm{OH})_{2}$ (水酸アパタイト, 以下 HAp と略記) を充填剤として, 生体高分子の分離を行った ${ }^{4)}$. Bernardi らは HAp を充填剂と して, 数多くの基礎的実験を行っている(5) 8). Gorbunoff ら は, タンパク質の吸着機構が主にイオン的な相互作用でめるこ とを明らかにした ${ }^{9)}$ 11). 川崎らは，陽イオン交換基と陰イオ ン交換基の 2 種類の吸着部位があり，代表的な結晶面である $(h 00)$ 面之 $(00 l)$ 面に，独立に分布するとしている12) 14). また， Spencer らは各種リン酸カルシウムを充填剤として, 吸着特性

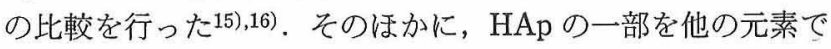
置換した, $\mathrm{Ca}_{10}\left(\mathrm{PO}_{4}\right)_{6} \mathrm{~F}_{2}{ }^{17)}$ や $\mathrm{Sr}_{10}\left(\mathrm{PO}_{4}\right)_{6}(\mathrm{OH})_{2}{ }^{18)}$ のクロマト 特性を検討した例も報告されている.

著者らは, $\mathrm{HAp}$ 類似化合物の一つである $\mathrm{Ca}_{8} \mathrm{H}_{2}\left(\mathrm{PO}_{4}\right)_{6}$. $5 \mathrm{H}_{2} \mathrm{O}$ （リン酸八カルシウム, 以下 OCP と略記）の表面化学 的な性質に注目した. 結晶構造中にはHAp とよく似た構造を 持つ $\mathrm{HAp}$ 類似層と, 水とリン酸のシートからなる水和層があ り,これらは, OCP の $(h 00)$ 面に対して交互に積層した構造 を持つ19),20). また, $\alpha-\mathrm{Ca}_{3}\left(\mathrm{PO}_{4}\right)_{2}$ (以下 $\alpha$-TCP と略記) の加 水分解によって合成した OCP は, 合成溶液中にジカルボン酸 が共存すると，インターカレーションを生じて複合体を生成す ることが知られている21) 25)。つまり, OCP は有機成分との 親和性も高く, 生体高分子に対する特異的な吸着特性が期待で きる。

本研究では, OCP を充填剤としたタンパク質の吸着特性を, 2 種類の形態の異なる $\mathrm{HAp}$ とも比較した，溶離液にはリン酸 カリウム緩衝溶液 $\left(\mathrm{K}_{2} \mathrm{HPO}_{4}\right.$ と $\mathrm{KH}_{2} \mathrm{PO}_{4}$ の等モル混合溶液, 以下 $\mathrm{KP}), \mathrm{KCl}, \mathrm{MgCl}_{2}$ を使用した. 20 種類のタンパク質に対 する溶出濃度をタンパク質の等電点（isoelectric point, 以下
pI）により分類して, OCP の吸着機構とその表面構造につい て考察した.

\section{2. 実 験}

\section{1 試料の調製}

OCP は $\alpha$-TCP の加水分解反応により以下のように合成し た. まず, $\mathrm{CaHPO}_{4} \cdot 2 \mathrm{H}_{2} \mathrm{O}$ (関東化学製, 特級試薬) と $\mathrm{CaCO}_{3}$ (関東化学製, 特級試薬) をモル比 $2: 1$ となるように混合し, $1000^{\circ} \mathrm{C}$ で $3 \mathrm{~h}$ 焼成後, 粉研, この操作を計 3 回繰り返し, $\beta$ $\mathrm{Ca}_{3}\left(\mathrm{PO}_{4}\right)_{2}$ (以下 $\beta$-TCP と略記) を得た。 $\alpha$-TCP は, $\beta$-TCP を $1300^{\circ} \mathrm{C}$ で $1 \mathrm{~h}$ 焼成し, 空冷して得た. OCP は $\alpha$-TCP $60^{\circ} \mathrm{C}$ の0.5 $\mathrm{mol} \cdot \mathrm{dm}^{-3} \mathrm{CH}_{3} \mathrm{COONa} \cdot 3 \mathrm{H}_{2} \mathrm{O}$ 水溶液中でかくはんしな がら, 希 $\mathrm{HNO}_{3}$ で $\mathrm{pH} 5.5$ に $2 \mathrm{~h}$ 保持し, 沪過後, $37^{\circ} \mathrm{C}$ で乾燥 して調製した. 形態の異なる 2 種類の HAp（以下 a-HAp, cHAp と略記）は次のようにして合成した，a-HAp は， $\alpha$-TCP を $80^{\circ} \mathrm{C}$ の水溶液中でかくはんしながら $\mathrm{NaOH}$ 水溶液で $\mathrm{pH} 10$ に $2 \mathrm{~h}$ 保持し, 沪過, 乾燥させて合成した. c-HApは, オー プンカラム式液体クロマトグラフィー用の充填剂として利用さ れていた Tiselius らの報告する HAp の合成方法と類似した方 法により合成した4)。すなわち， $\mathrm{CaHPO}_{4} \cdot 2 \mathrm{H}_{2} \mathrm{O}$ を 30 mass $\%$ $\mathrm{NaOH}$ 水溶液中に投入し, $90 \sim 95^{\circ} \mathrm{C} て ゙ 1 \mathrm{~h}$ 保持, 数回のデカ ンテーションによって微細な結晶を取り除き, 沪過, 乾燥して 得た.

各合成試料は粉末 X 線回折 (XRD) により同定し, 走査型 電子顕微鏡（SEM）により形態の観察を行った. 比表面積は BET 吸着法により測定した。

試料分子として使用したタンパク質の種類と $\mathrm{pI}$ は表 1 に示 す.

2.2 液体クロマトグラフィー

測定には, イオンクロマトグラフ (Dionex 製, 2000i/SP) の一部不要な部品を取り除いて使用した。 カラムは PEEK (Poly Ether Ether Ketone) 製の $4 \mathrm{~mm}$ (内径) $\times 250 \mathrm{~mm}$ (長 
Table 1. Proteins Used for Chromatography

\begin{tabular}{clc}
\hline No. & Protein (Source) & $\mathrm{pI}^{\mathrm{a}}$ \\
\hline 1 & Pepsin (Porcine Stomach Mucosa) & 1.0 \\
2 & Lactalbumin (Milk) & 4.5 \\
3 & Trypsin inhibitor (Soybean) & 4.6 \\
4 & Ovalbumin (Chicken Egg Serum) & 4.6 \\
5 & Albumin (Bovine Serum) & 4.8 \\
6 & $\alpha$-Amylase (Porcine) & 4.9 \\
7 & $\beta$-Lactoglobulin A (Bovine Milk) & 5.1 \\
8 & $\beta$-Lactoglobulin B (Bovine Milk) & 5.1 \\
9 & Insulin (Bovine Pancreas) & 5.5 \\
10 & holo-Transferrin (Bovine) & 5.5 \\
11 & Catalase (Bovine Liver) & 5.6 \\
12 & Conalbumin (Chicken Egg White) & 6.4 \\
13 & Hemoglobin (Bovine) & 7.0 \\
14 & Myoglobin (Horse Skeletal Muscle) & 8.1 \\
15 & r-Chymotrypsin (Bovine Pancreas) & 8.4 \\
16 & Papain (Papaya Latex) & 9.2 \\
17 & Trypsinogen (Bovine Pancreas) & 9.3 \\
18 & Ribonuclease A (Bovine Pancreas) & 9.5 \\
19 & Cytochrome c (Horse Heart) & 10.1 \\
20 & Lysozyme (Egg White) & 11.2 \\
\hline
\end{tabular}

a) Isoelectric point.

さ）を使用した. カラムへの試料の充填は, 合成試料を蒸留水 に縣濁し, 垂直に立てたカラム内へ流入し, 自然沈降させた.

カラム内の充填剤は結晶表面の化学的な変化を配慮して毎日交 換した。初期溶離液は, $\mathrm{PO}_{4}{ }^{3-}$ イオン濃度で $0.01 \mathrm{~mol} \cdot \mathrm{dm}^{-3}$ の $\mathrm{KP}\left(\mathrm{K}^{+}\right.$イオン濃度では, $\mathrm{K}_{2} \mathrm{HPO}_{4}$ と $\mathrm{KH}_{2} \mathrm{PO}_{4}$ の等モル混 合溶液のため, $\mathrm{PO}_{4}{ }^{3-}$ イオン濃度の1.5倍として計算され， $0.015 \mathrm{~mol} \cdot \mathrm{dm}^{-3}$ となる. 以後 $\mathrm{KP}$ 濃度はすべて $\mathrm{PO}_{4}{ }^{3-}$ イオン 濃度で表す）を加えて, $\mathrm{pH} \approx 6.8$ に保持した. 直線濃度勾配法 による測定には $\mathrm{KP}$ あるいは $\mathrm{KCl}, \mathrm{MgCl}_{2}$ をそれぞれ使用した. $\mathrm{KCl}, \mathrm{MgCl}_{2}$ を溶離液として直線濃度勾配溶出を行った場合に は, $\mathrm{pH}$ を一定に保つために $0.01 \mathrm{~mol} \cdot \mathrm{dm}^{-3} \mathrm{KP}$ を共存させた. $\mathrm{KP}$ 溶離液の濃度勾配は $4.9 \mathrm{~mol} \cdot \mathrm{dm}^{-3}\left(\mathrm{~K}^{+}\right.$イオン濃度で表せ ば, $\left.7.4 \mathrm{~mol} \cdot \mathrm{dm}^{-3}\right), \mathrm{KCl}, \mathrm{MgCl}_{2}$ を溶離液とした濃度勾配は, $5.0 \mathrm{~mol} \cdot \mathrm{dm}^{-3}$ でそれぞれ行った。溶離液中の無機イオン濃度 の測定にはアッべ式の屈折計を用いた. タンパク質はそれぞれ の溶解度之検出感度に合わせて, $0.01 \mathrm{~mol} \cdot \mathrm{dm}^{-3} \mathrm{KP}$ で 1 10 $\mathrm{g} \cdot \mathrm{dm}^{-3}$ の濃度に調製して50〜 $100 \mu \mathrm{l}$ 注入した．タンパク質の 検出は紫外分光検出器を用いて $280 \mathrm{~nm}$ で行った。流速は 0.5 $2.0 \mathrm{ml} \cdot \mathrm{min}^{-1}$ となるように調整した. なお, 濃度勾配法にお いて, 試料分子の溶出濃度は溶離液の流速に依存しないことが 報告されている26)，測定はすべて室温で行った．

\section{3. 結果と考察}

3.1 試料のキャラクタリゼーション

図 1 に, (a) OCP, (b) a-HAp と (c) c-HAp の XRD 回折図 を示す。それぞれが単一相であることを確認した. c-HAp は, $(00 l)$ 面の回折線が相対的に強く現れ, $750^{\circ} \mathrm{C} て ゙ ~ 1 \mathrm{~h}$ 加熱処理す

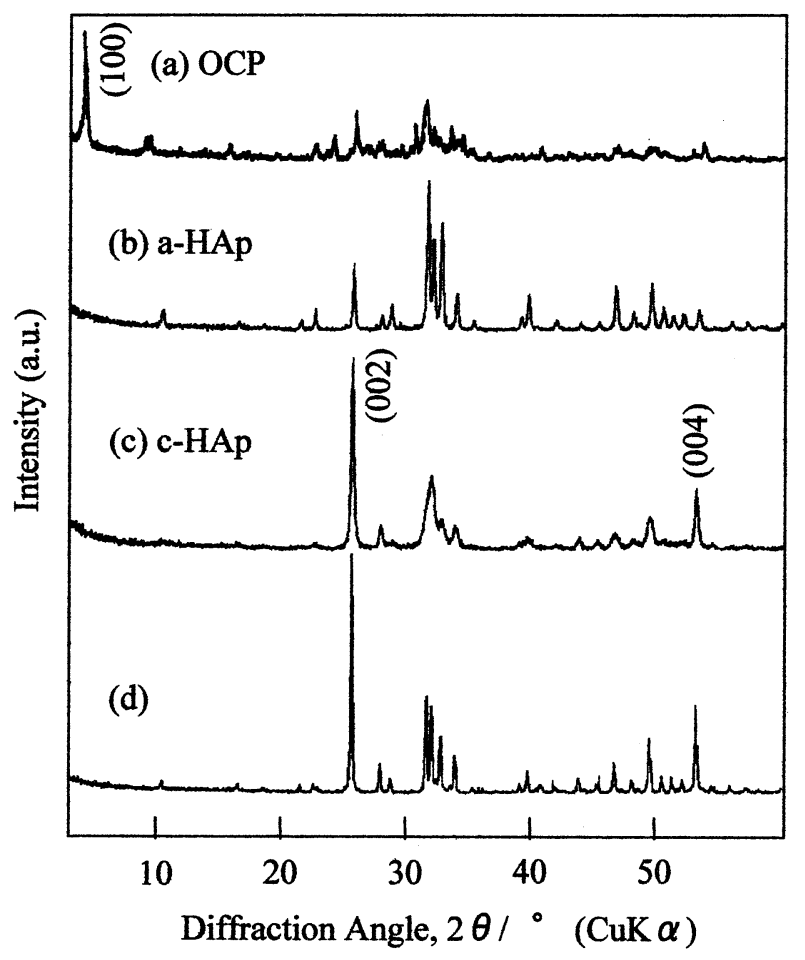

Fig. 1. XRD patterns of prepared OCP and HAp packed columns. (a) OCP, (b) a-HAp, (c) c-HAp, (d) (c) heated at $750^{\circ} \mathrm{C}$ for $1 \mathrm{~h}$.

ると, (d)のように結晶性が向上して, その特徵はより明確に なった. 図 2 には, 各試料の一次粒子と二次粒子の外形の確認 できる SEM 写真を示す. OCP の一次粒子は OCP 特有の板状 形態27)であった. OCP の(100)面の回折強度と形態の観察か ら, 板状表面は $(h 00)$ 面であると推測された. a-HAp は, 原料 として用いた $\alpha$-TCP 焼結粒子の外形をとどめて, クモの巣状 に一次粒子を絡み合わせていた。 OCP 及びa-HAp の比表面積

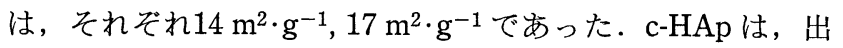
発原料である $\mathrm{CaHPO}_{4} \cdot 2 \mathrm{H}_{2} \mathrm{O}$ の外形を保ち, 大きな板状表面 に微細な針状結晶を䋊密に集合させていた. XRD 回折図との 対応から, c-HAp は大きな板状平面と垂直の方向に $c$ 軸を配 向した凝集粒子であると推定された. 比表面積は $97 \mathrm{~m}^{2} \cdot \mathrm{g}^{-1}$ で あった。

\section{2 タンパク質溶出挙動}

図 3 は, OCP, a-HAp, c-HAp を充填剂として, 牛血清アル ブミン（ $\mathrm{pI}=4.8$, 以下 BSA と略記）, ウマシトクロム $\mathrm{c}(\mathrm{pI}=$ $10.1)$, 卵白リゾチーム $(\mathrm{pI}=11.2)$ の混合タンパク質を試料 分子として, KPにより直線濃度勾配法で測定したクロマトグ ラムである。これらの混合タンパク質は初期溶離液の 0.01 $\mathrm{mol} \cdot \mathrm{dm}^{-3} \mathrm{KP}$ では溶出しなかった. しかし, 溶離液中の $\mathrm{KP}$ 濃度勾配を $4.9 \mathrm{~mol} \cdot \mathrm{dm}^{-3}$ の割合で直線的に上昇させると, OCP 充填カラムでは, 卵白リゾチーム（溶出濃度 $\left(M_{\mathrm{elu}}\right)=$ $\left.0.06 \mathrm{~mol} \cdot \mathrm{dm}^{-3}\right), \mathrm{BSA}\left(M_{\mathrm{elu}}=0.08 \mathrm{~mol} \cdot \mathrm{dm}^{-3}\right)$, ウマシトクロ 厶 $\mathrm{c}\left(M_{\mathrm{elu}}=0.14 \mathrm{~mol} \cdot \mathrm{dm}^{-3}\right)$ の順に溶出した. a-HAp 及び cHAp 充媜力ラムでは，それぞれ, BSA $\left(M_{\mathrm{elu}}=0.05,0.04\right.$ $\left.\mathrm{mol} \cdot \mathrm{dm}^{-3}\right)$, 卵白リゾチーム $\left(M_{\mathrm{elu}}=0.08,0.15 \mathrm{~mol} \cdot \mathrm{dm}^{-3}\right)$, ウマシトクロム c $\left(M_{\mathrm{elu}}=0.16,0.23 \mathrm{~mol} \cdot \mathrm{dm}^{-3}\right)$ の溶出順位と なり, OCP 充填カラムの溶出順位とは異なった. 個々のタン パク質のクロマトグラムピーク形状と溶出濃度は, 試料分子を 個別に測定した場合ともほほ一致することを別に確認した。

図 4 は, OCP, a-HAp, c-HAp の各充填剤において, 二重濃 

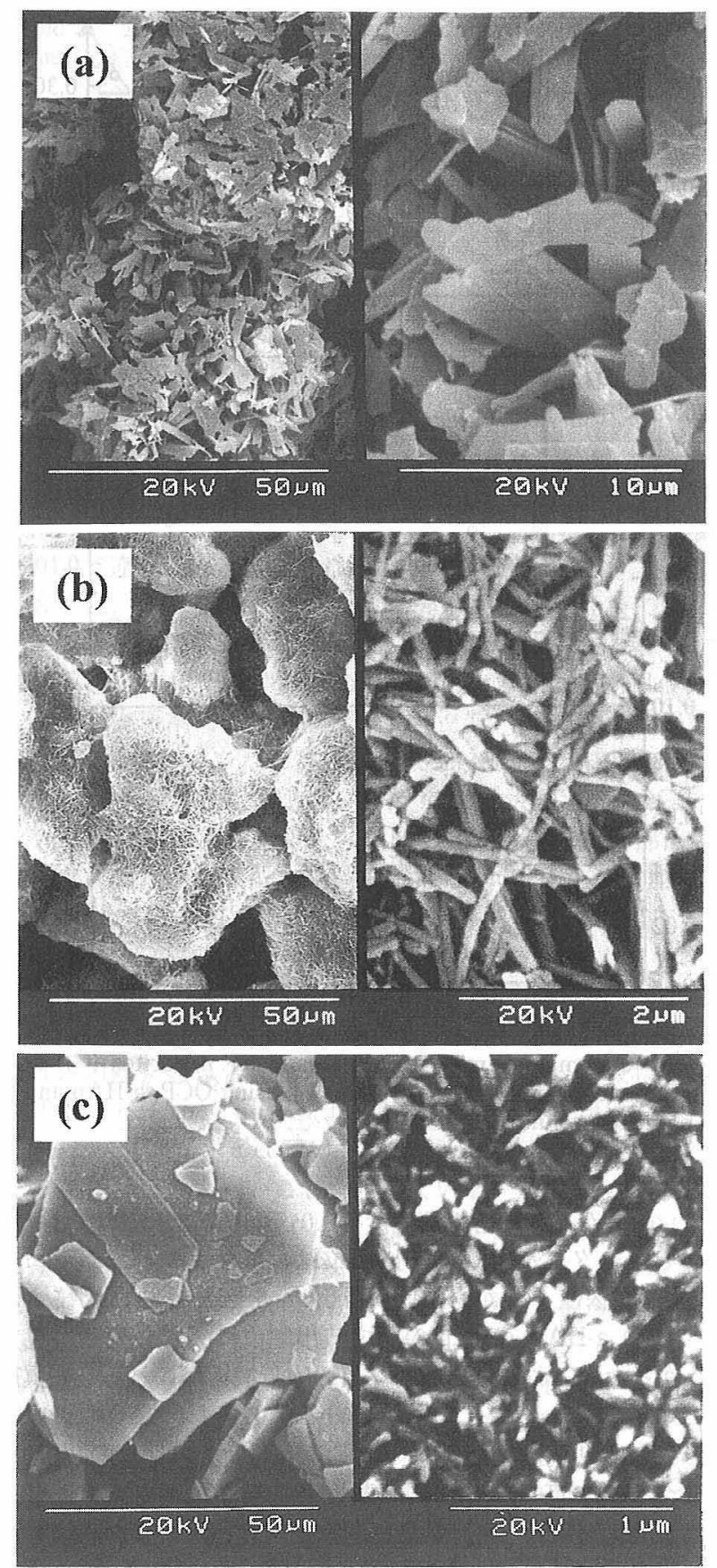

Fig. 2. SEM photographs of OCP and two types of HAp. (a) OCP, (b) a-HAp, (c) c-HAp.

度勾配溶出法により測定した混合タンパク質のクロマトグラム である。始めに， $\mathrm{KCl}$ を溶離液として直線濃度勾配溶出を行 い，続いて，KPによって直線濃度勾配溶出を行った，OCP を充填剤としてこの操作を行うと, 塩基性タンパク質の卵白リ ゾチームとウマシトクロム $\mathrm{c}$ が $\mathrm{KCl}$ によって溶出し, 酸性タ ンパク質の $\mathrm{BSA}$ は $0.3 \mathrm{~mol} \cdot \mathrm{dm}^{-3}$ 以上になっても溶出しな かった。しかし，溶離液を $\mathrm{KP} に$ 交換すると，BSAは0.07 $\mathrm{mol} \cdot \mathrm{dm}^{-3}$ で溶出した. このような溶出挙動は $\mathrm{c}-\mathrm{HAp}, \mathrm{a}-\mathrm{HAp}$ においても同様であった。 また，図 5 に示すように, $\mathrm{MgCl}_{2}$ と KPによって二重濃度勾配溶出を行うと, OCP, a-HAp, cHAp のいずれの充填剤においても塩基性タンパク質は $\mathrm{MgCl}_{2}$ によって溶出し， $\mathrm{KCl}$ を溶離液として濃度勾配溶出したより も極端に低濃度の溶離液濃度で溶出した。 しかし, 酸性タンパ
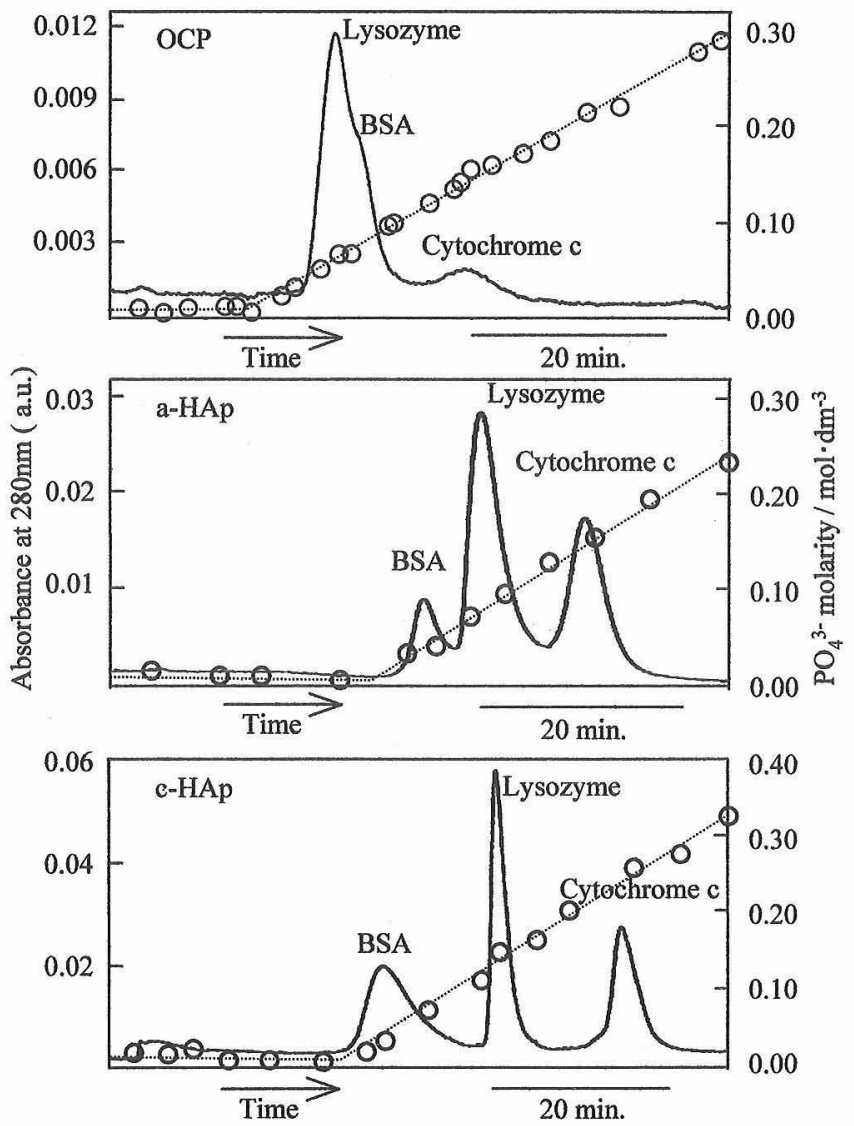

Fig. 3. Chromatograms with KP molarity $(O)$ gradient of proteins by using OCP, a-HAp and c-HAp packed columns.

ク質は $0.3 \mathrm{~mol} \cdot \mathrm{dm}^{-3}$ 以上の $\mathrm{MgCl}_{2}$ によっても溶出しなかっ た.

\section{3 タンパク質吸一脱着機構}

川崎らは, HAp クロマトグラフィーに抢けるタンパク質の 吸着に及ぼす溶離液中の無機イオンの影響を次のように解釈し

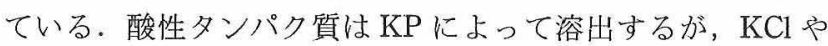
$\mathrm{MgCl}_{2}$ では溶出しない。一方, 塩基性タンパク質は, $\mathrm{KP}$, $\mathrm{KCl}$ や $\mathrm{MgCl}_{2}$ いずれの溶離液によっても溶出する。つまり, 酸性タンパク質の溶出には, $\mathrm{K}^{+}$イオンや $\mathrm{Cl}^{-}$イオンがほとん

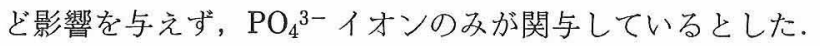
塩基性タンパク質は, $\mathrm{KP}, \mathrm{KCl}$ のどちらの溶離液中でもほぼ 同様に溶出し，2 価の電荷を持った $\mathrm{Mg}^{2+}$ イオンにより，更に 低濃度の溶離液で溶出することから， $\mathrm{K}^{+} や \mathrm{Mg}^{2+}$ が溶出に関 与しているとした，ただし， $\mathrm{Cl}^{-}$イオンによって酸性タンパク 質が溶出しないのは， $\mathrm{Cl}^{-}$イオンの競合吸着力が他の分子に比 ベて極端に弱いためと推定した ${ }^{14)}$.

本実験では，各種溶離液中における HAp と OCP のタンパ ク質溶出挙動が一致していることから, 酸性タンパク質は負の 電荷を持った吸着官能基（カルボキシル基や，リンタンパク質 の場合はリン酸基も含む）を用いて, 溶離液中の負電荷を持っ た無機イオンと競合しながら, OCP やHAp 結晶表面上に存

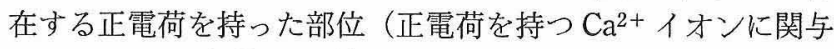
するので， $\mathrm{Ca}$ 部位と仮称）とそれぞれ吸着すると推定した。 一方, 塩基性タンパク質は, 正の電荷を持った吸着官能基（ア ミノ基やグアニジノ基）を利用して, 溶離液中の正電荷を持っ た無機イオンと競合しながら，OCP H HApの結晶表面上に 存在する負電荷を持った部位（負電荷を持つ $\mathrm{PO}_{4}{ }^{3-} イ$ オに 

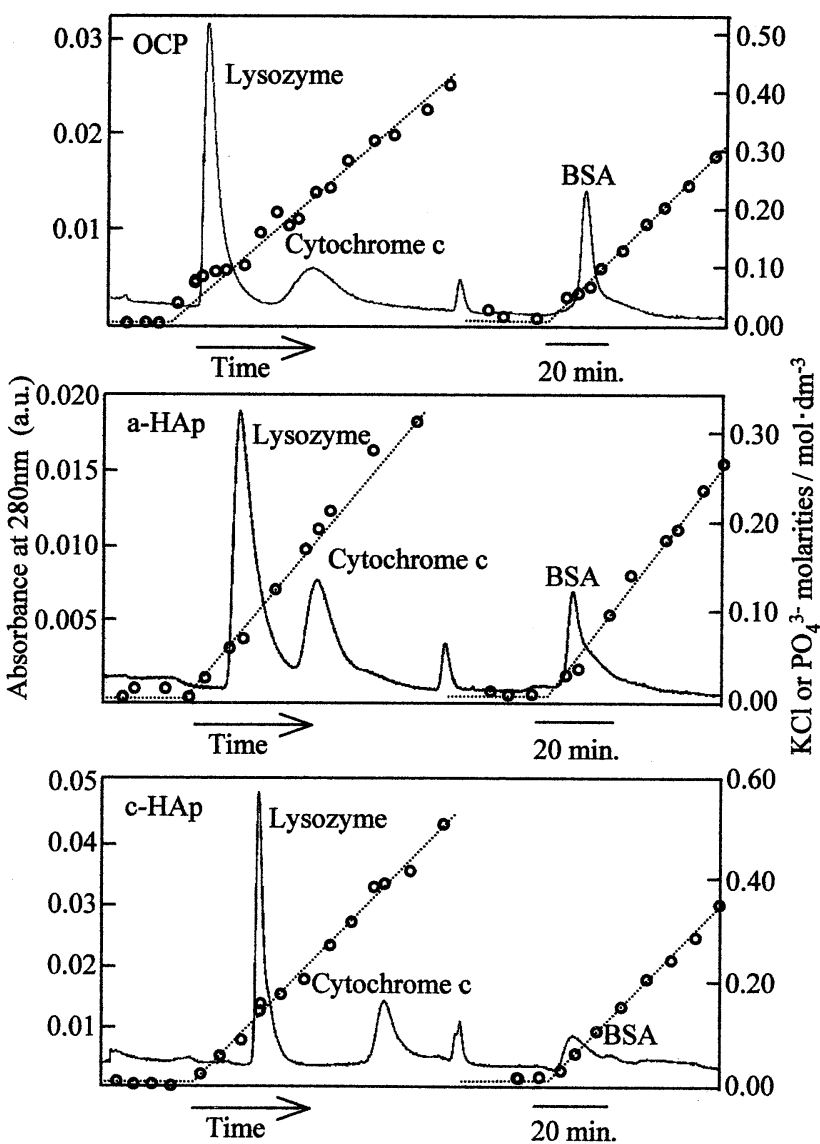

Fig. 4. Chromatograms with $\mathrm{KCl}$ and $\mathrm{KP}$ molarities $(\bigcirc)$ double gradient for mixtures of proteins by using OCP, a-HAp and c-HAp packed columns.

関与するので，P 部位と仮称）とそれぞれ吸着すると推定し た.

図 6 は, KP を溶離液として, OCP, a-HAp, c-HAp を充媜 凨とした，表 1 に記載する 20 種類のタンパク質の主要なクロ マトグラムピーク頂点における溶出濃度と pI の関係を示す. タンパク質の種類は, 表中の番号によってそれぞれ表した．前 述の推定から, 酸性タンパク質は $\mathrm{Ca}$ 部位に，塩基性タンパク 質は P 部位に吸着するとして, 酸性タンパク質 $(\mathrm{pI}<6.8$, と塩基性タンパク質（pI $>6.8,0$ ）を区別して示した. 3 種類 の充填剤に共通して, 20 種類のタンパク質は $0.3 \mathrm{~mol} \cdot \mathrm{dm}^{-3}$ 以 下の KP ですべて溶出した. ウシラクトアルブミンとブタイン

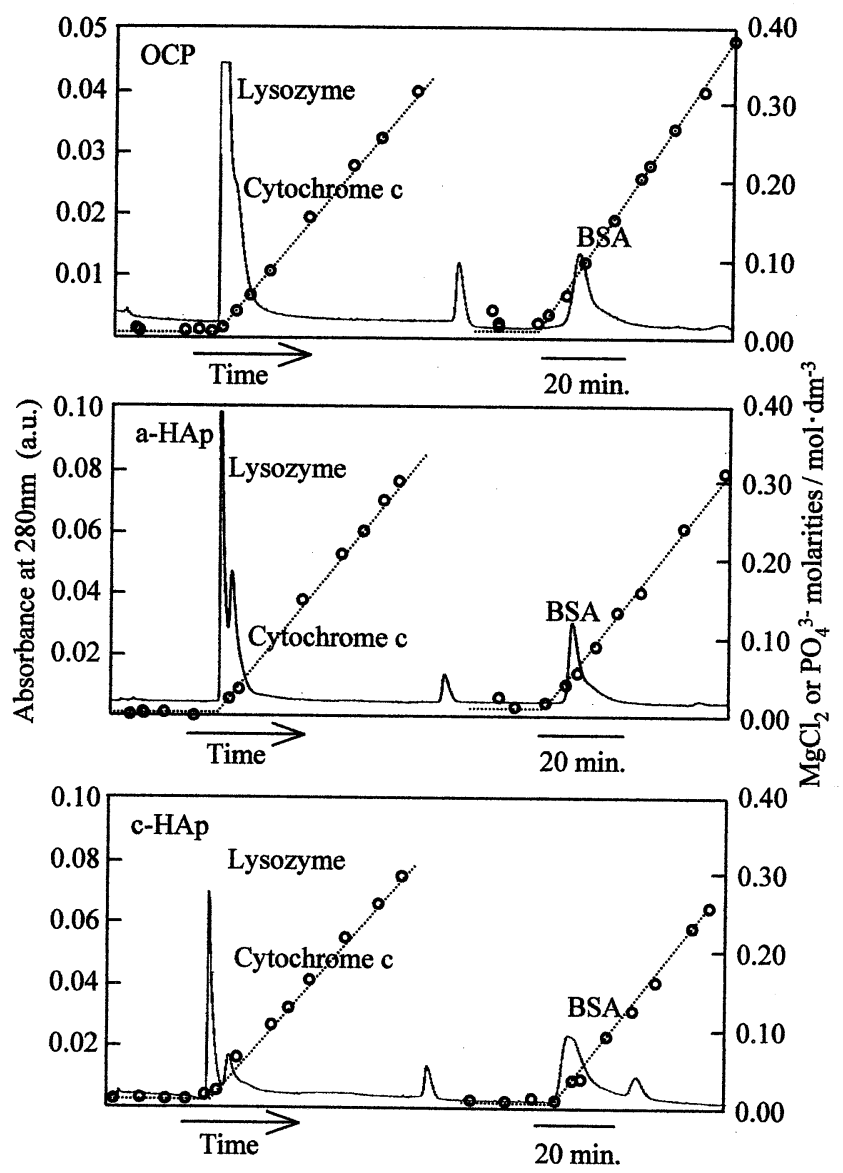

Fig. 5. Chromatograms with $\mathrm{MgCl}_{2}$ and $\mathrm{KP}$ molarites $(\bigcirc)$ double gradient for mixtures of proteins by using OCP, a-HAp and cHAp packed columns.

スリンのみが，初期溶離液濃度の $0.01 \mathrm{~mol} \cdot \mathrm{dm}^{-3} \mathrm{KP}$ によって 溶出した。タンパク質の溶出順位は，酸性タンパク質 $(\mathrm{pI}<$ 6.8 ） と塩基性タンパク質（pI>6.8）を区分けして比較すれ ば, OCP, a-HAp, c-HAp の間で溶出順位に大きな変動は見ら れなかった。これは, タンパク質の吸着機構がこれらの充填剤 間で類似していることを示している。しかし，図3のクロマ トグラムに見られるように, OCP と a-HAp, c-HAp の間では, 酸性タンパク質 (BSA) と塩基性タンパク質（ウマシトクロ ムc，卵白リゾチーム）の溶出順位が異なった，また，図6で も，酸性タンパク質 $(\mathrm{pI}<6.8)$ と塩基性タンパク質（pI>6.8） の溶出濃度の比は各充填剂間で異なった。一般に，タンパク質
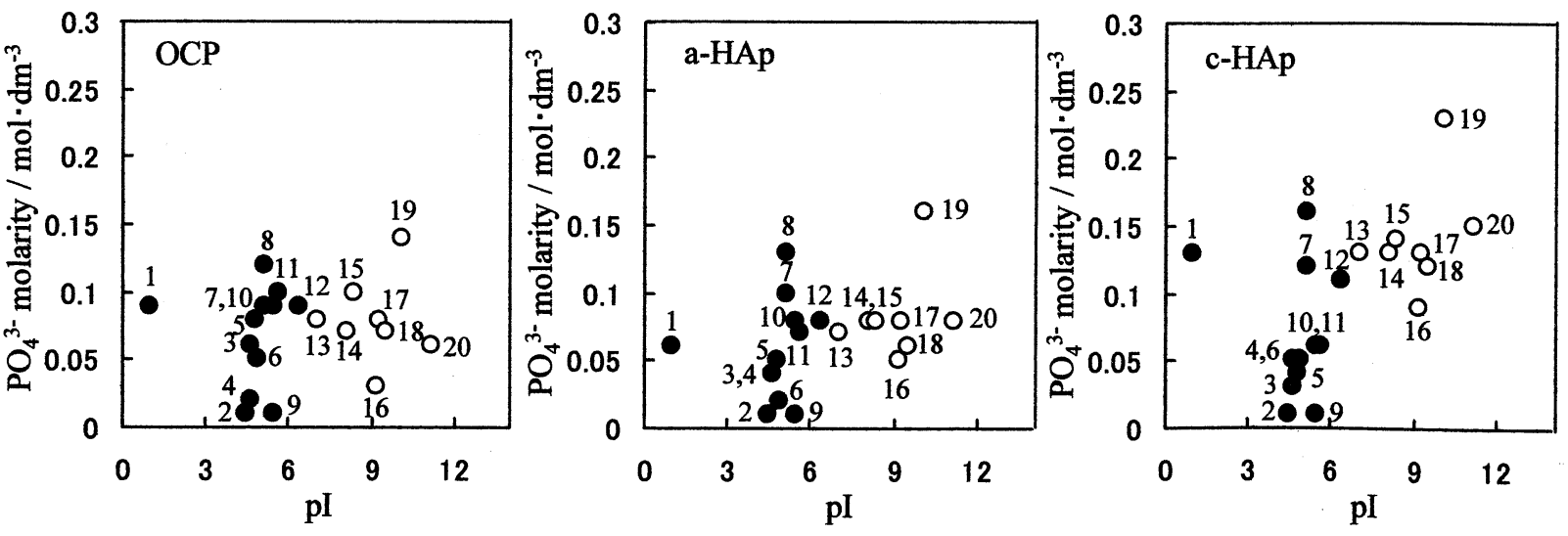

Fig. 6. Plots of elution molarity vs. pI for acidic and basic $(\bigcirc)$ proteins by using OCP, a-HAp and c-HAp packed columns. 
Table 2. Average Relative Elution Moralities of Acidic Basic (O) Proteins

\begin{tabular}{ccc}
\hline OCP & a-HAp & c-HAp \\
\hline 0.86 & 0.70 & 0.49 \\
\hline
\end{tabular}

は移動相（溶離液）の移動に伴った吸脱着の繰り返しによって 溶出するため, カラム内での吸着部位との相互作用の多いもの ほど遅れて溶出する．したがって, 酸性タンパク質 $(\mathrm{pI}<6.8)$ と塩基性タンパク質（pI>6.8）の溶出濃度に違いが見られた のは, 充填剤表面に存在する $\mathrm{Ca}$ 部位と $\mathrm{P}$ 部位の数が各充填剂 によって違うためと考えられる。

表 2 は, OCP, a-HAp, c-HAp の充填率や比表面積に依存せ ず, 結晶表面に存在する $\mathrm{Ca}$ 部位と $\mathrm{P}$ 部位の相対的な存在比を 表す数值として比較するために, 図 7 より求まる各リン酸力 ルシウム充填剈における酸性タンパク質（pI $<6.8 ）$ の平均溶 出濃度と塩基性タンパク質 $(\mathrm{pI}>6.8)$ の平均溶出濃度の比（以 下○/○と略記）を計算した. ○/○の值の大きさは, OCP $>$ a$\mathrm{HAp}>\mathrm{c}-\mathrm{HAp}$ の順であった。 川崎らは, $\mathrm{HAp}$ の $\mathrm{Ca}$ 部位と $\mathrm{P}$ 部位は，異なる代表的な結晶面である $(h 00)$ 面と $(00 l)$ 面にそ れぞれ独立に分布すると報告している13),14). 本実験では， (00l)面を配向凝集した c-HAp が，柱状の a-HAp よりもの/O の值の小さいことから，(h00)面には $\mathrm{Ca}$ 部位が多く分布し, $(00 l)$ 面には $\mathrm{P}$ 部位の多く分布することが予想される．この結 果は, 川崎らの報告とも矛盾しなかった. 更に, 板状形態の OCP は, c-HAp やa-HAp よりもの/○の值が大きくなった. これは, c-HAp やa-HAp よりも, OCP の方が $\mathrm{Ca}$ 部位/P 部 位の存在割合の大きいことを示している. 一般に, OCP の結 晶は[001]方向に成長しやすく, 図 2 (a)の板状平面は $(h 00)$ 面 に対応すると推測される。 OCP の $(h 00)$ 面には, これと水平 にして HAp 類似層と水和層が，交互に積層した構造を持つ27). Brown らは, OCP 結晶構造に関する考察の中で, HAp の結 晶構造との類似性に着目して, HAp と水との接する界面には, OCP の水和層と類似の安定層が現れると予測している ${ }^{20)}$. 著 者らは, OCP と HApのタンパク質吸着機構が, 各種溶離液 中におけるタンパク質の溶出挙動と溶出順位より類似している ことを示した，そして, HApの $(h 00)$ 面に見られる結晶構造 と, OCP の $(h 00)$ 面に現れる結晶構造との対応関係より, OCP の $(h 00)$ 面には $\mathrm{Ca}$ 部位が多く存在していると推定した. しかし, OCP の $(0 k 0)$ 面と $(00 l)$ 面には, HAp 類似層と水和層 が交互に配列した構造が現れる.このような結晶面がどのよう な吸着特性を示すかについては明らかにすることができなかっ た.

\section{4. 結 論}

$\mathrm{OCP}$ を充填剤として液体クロマトグラフィーによりタンパ ク質の吸着特性を調べ, 吸着挙動と表面構造を HAp と比較し た結果，以下の結論を得た.

（1） KP を溶離液として濃度勾配法により溶出を行うと, 初期溶離液濃度の $0.01 \mathrm{~mol} \cdot \mathrm{dm}^{-3}$ でさまざまな $\mathrm{pI}$ を持つタン パク質が吸着し, $\mathrm{KP}$ 濃度の増加に伴って溶出した。

(2) $\mathrm{KCl}, \mathrm{MgCl}_{2}$ を溶離液に用いると, 塩基性タンパク質
は溶出するが, 酸性タンパク質は $0.3 \mathrm{~mol} \cdot \mathrm{dm}^{-3}$ 以上になって も溶出しなかった。この吸着挙動は HAp と類似しており, 酸 性タンパク質（ $\mathrm{pI}<6.8 ）$ を吸着する $\mathrm{Ca}$ 部位と, 塩基性タン パク質（pI>6.8）を吸着する $\mathrm{P}$ 部位の 2 種類の吸着部位の存 在が推定された.

（3） 20 種類のタンパク質の溶出順位は，酸性タンパク質と 塩基性タンパク質を区分けして比較すると, HAp と大差が見 られなかった。これは OCP と HAp の吸着機構が類似してい ることを示している.

（4）酸性タンパク質の平均溶出濃度と塩基性タンパク質の 平均溶出濃度の比は, a-HAp, c-HAp よりも OCP の方が大き くなった。これは, HApの $(h 00)$ 面と類似の構造を持った OCP の $(h 00)$ 面が，HAp の $(h 00)$ 面に $\mathrm{Ca}$ 部位を多く持つのと 同じように，板状に発達した OCP の $(h 00)$ 面にも Ca 部位を多 く持つためと予想した.

謝辞 本研究に当たり, 適切なご助言を頂きました国際解 析研究所・川崎 力博士に心から感謝の意を表します.

\section{文 献}

1) K. Agner, Biochem. J., 32, 1702-06 (1938).

2) B. D. Polis and H. W. Shmukler, J. Biol. Chem., 201, 475500 (1953).

3) C. A. Zittle, Advance in Enzymol., 14, 319-74 (1953).

4) A. Tiselius, S. Hjertén and Ö. Levin, Arch. Biochem. Biophys., 65, 132-55 (1956).

5) G. Bernardi, Methods Enzymol., 21, 95-139 (1971).

6) G. Bernardi, Methods Enzymol., 22, 325-39 (1971).

7) G. Bernardi, Methods Enzymol., 27, 471-79 (1973).

8) G. Bernardi, M. G. Giro and C. Gaillard, Biochim. Biophys. Ac$t a, 278,409-20$ (1972).

9) M. J. Gorbunoff, Anal. Biochem., 136, 425-32 (1984).

10) M. J. Gorbunoff, Anal. Biochem., 136, 433-39 (1984).

11) M. J. Gorbunoff and S. N. Timasheff, Anal. Biochem., 136, 440-45 (1984).

12) T. Kawasaki, M. Niikura and Y. Kobayashi, J. Chromatogr., 515, 91-123 (1990).

13) T. Kawasaki, M. Niikura and Y. Kobayashi, J. Chromatogr., 515, 125-48 (1990).

14) T. Kawasaki, J. Chromatogr., 544, 147-84 (1991).

15) M. Spencer and M. Grynpas, J. Chromatogr., 166, 423-34 (1978).

16) M. Spencer, J. Chromatogr., 166, 435-46 (1978).

17) T. Sato, T. Okuyama, T. Ogawa and M. Ebihara, Bunseki Kagaku, 38, 34-39 (1989) [in Japanese].

18) T. Kawasaki, M. Niikura, S. Takahashi and W. Kobayashi, Biochem. Int., 15, 1137-49 (1987).

19) M. Mathew, W. E. Brown and L. W. Schroeder, J. Crystallogr. Spectrosco. Res., 18, 235-50 (1988).

20) W. E. Brown, M. Mathew and M. S. Tung, Prog. Crystal Growth Charact., 4, 59-87 (1981).

21) H. Monma and M. Goto, Bull. Chem. Soc. Jpn., 56, 3843-44 (1983).

22) H. Monma, Bull. Chem. Soc. Jpn., 57, 599-600 (1984).

23) M. Markovic, B. O. Fowler and W. E. Brown, Chem. Mater., 5, 1401-05 (1993).

24) M. Marković, B. O. Fowler and W. E. Brown, Chem. Mater., 5, 1406-16 (1993).

25) M. Marković, B. O. Fowler and W. E. Brown, Chem. Mater., 5, 1417-23 (1993).

26) T. Kawasaki and M. Niikura, Sep. Sci. Technol., 25, 397-435 (1990).

27) J. C. Elliott, "Structure and Chemistry of the Apatites and Other Calcium Orthophosphates," Vol. 18, Elsevier Science (1994) pp. 12-15. 